\title{
Composted slaughterhouse sludge as a substitute for chemical fertilizers in the cultures of lettuce (Lactuca sativa $\mathrm{L}_{\text {.) }}$ and radish (Raphanus sativus $\mathrm{L}_{\text {.) }}$
}

José Juscelino de OLIVEIRA ${ }^{1 \star}$, Gabriel Ollé DALMAZO², Tânia Beatriz Gamboa Araújo MORSELLI³ Vanderleia Fátima da Silva de OLIVEIRA ${ }^{4}$, Luciara Bilhalva CORRÊA ${ }^{5}$, Leonardo NORA ${ }^{2}$, Érico Kunde CORRÊA ${ }^{5}$

\begin{abstract}
Flotation sludge (FS) is produced in huge amounts at slaughterhouses in western Santa Catarina, Brazil. This waste is rich in plant nutrients and a valuable resource for soil amendments. Five FS composts were tested as a replacement for chemical fertilizers (QF), namely T1 (75\% poultry manure (PM) and 25\% sawdust (SD)); T2 (50\% PM and 50\% SD); T3 (25\% PM and 75\% SD); T4 (100\% PM and 0\% SD); and T5 (0\% PM x 100\% SD). For lettuce plants, treatments containing composted FS resulted in an increased number of leaves, leaf area and leaf fresh weight (LFW). T1 presented the best results with increases of 1.4 fold in LFW compared to plants supplemented with QF. T2 was the most effective treatment for radish with the best results of root fresh weight and root diameter. Although T4 had the highest nitrogen content, it did not present the best results in growth performance for lettuce or radish. The presence of higher proportions of SD in composts ( $25 \%$ for lettuce and $50 \%$ for radish) improved the physical characteristics of the soil and proved to be a more balanced compost.
\end{abstract}

Keywords: biosolid; organic compost; poultry manure; sawdust; flotation sludge.

Practical Application: Floatation sludge successfully replaced chemical fertilizers in the cultures of lettuce and radish.

\section{Introduction}

One of the major challenges facing modern agriculture is to develop sustainable production systems that can produce enough quality food without compromising environmental resources (Ahlburg et al., 2013). The region located in western Santa Catarina state (southern Brazil) is known for its high concentration of pig and broiler chicken farms and abattoirs, where 10.8 million pigs and 1.7 billion broiler chickens were slaughtered in 2015. Due to these quantities, Santa Catarina is ranked as the largest agro-industrial complex in South America.

Abattoirs treat the water used in the production line by flocculation and flotation process, resulting in a protein rich (flocculated) and fat rich (flotation) sludge. Average sized abattoirs are estimated to produce approximately $80,000 \mathrm{~kg}$ of waste (slaughterhouse sludge) per day (2013 data), which must be stabilized. Given such huge volumes, composting becomes the process of choice, due to low technological demands and reduced costs. However, slaughterhouse sludge is periodically disposed in landfills because of the huge amounts, consequently becoming an environmental threat. This type of waste is of a valuable resource, since it can be stabilized by composting and become nutrient-rich fertilizers.

Technical feasibility of organic fertilization can be evaluated with the help of growth performance experiments, where plant development standards respond to different organic fertilizers (Klerkx et al., 2012). In this context, lettuce (Lactuca sativa L.) and radish (Raphanus sativus L.) figure as good models for growth performance studies. Lettuce is known for its high nutrient demands and presents satisfactory responses to organic fertilization (Brasil et al., 2007). Likewise, radish is a short-cycle crop and demands high amounts of nutrients in order to complete its life cycle (Linhares et al., 2010).

Organic fertilization is particularly interesting in the case of vegetable production in western Santa Catarina, which is practically comprised of small properties $(<10 \mathrm{ha})$ that rely on family workforce. The increasing costs of chemical fertilizers is another reason to adopt the use of organic fertilization (Montemurro et al., 2015).

Despite the increasing incentives for the adoption of organic fertilizers, little information is available regarding the growth performance of vegetables when submitted to fertilization with composts obtained from slaughterhouse sludge. The objective of the present study was to evaluate the growth performance of lettuce and radish plants supplemented with floatation sludge compost (originated from swine and chicken slaughterhouses), composted with different proportions of bulking agents (poultry manure and sawdust). The specific objectives were: i) to determine which compost allows better vegetative performance for lettuce and radish; ii) to evaluate the agronomic responses of lettuce (aerial parts) and radish (roots); iii) to evaluate the nutrient 
intake of the cultures; and iv) to evaluate the residual effect of composts in soil.

\section{Material and methods}

\subsection{Compost origin and characteristics}

The composts used in soil amendment studies were obtained in previous experiments (data not published). Flotation sludge (FS), a fat-rich fraction derived from secondary decanters normally used in poultry and swine slaughterhouses, was composted with two different bulking agents, poultry manure (PM) and sawdust (SD), in five different proportions (v:v): T1 (75\% PM and 25\% SD); T2 (50\% PM and 50\% SD); T3 (25\% PM and 75\% SD); T4 (100\% PM and $0 \%$ SD); and T5 ( $0 \% \mathrm{PM} \times 100 \%$ SD). Composting piles contained $10 \mathrm{~m}^{3}$ of SD or PM (in the different proportions), and each pile received 5,000 L of FS. The composting process was carried out for 120 days. The final compost characterization is presented in Table 1.

\subsection{Plant material and cultivation}

Growth performance experiments were conducted in lettuce (Lactuca sativa, cv. Veneranda) and radish (Raphanus sativus, cv. Saxa) plants. Lettuce seedlings were produced in expanded polystyrene trays containing 128 cells (floating system) and fertilized peat was used as substrate. Seedlings were transplanted at the stage of two leaves to plastic bags containing $5 \mathrm{~kg}$ of sieved soil (2 $\mathrm{mm}$ sieve). Radish seeds were placed directly in $5 \mathrm{~kg}$ plastic bags. Irrigation was performed manually with three-day intervals. The criteria used was soil field capacity $(100 \%)$ and water demand of the cultures based on their fresh weight, in which lettuce plants received $1,282.5 \mathrm{~mL}$ ( $95 \%$ fresh weight) and radish plants $1,215 \mathrm{~mL}$ ( $90 \%$ fresh weight). The entire experiment (seedling production and vegetative phase) was carried out in a controlled temperature greenhouse covered with $0.15 \mathrm{~mm}$ low density polyethylene with UV blocker. Plants were protected from direct sunlight incidence with the help of shading fabrics (50\%). The soil used in the experiment is classified as Hydromorphic eutrophic solodic planosol containing: $25 \%$ of clay; $56 \%$ of sand; $24 \%$ of silt; $\mathrm{pH} 4.8 ; 1.5 \%$ of organic matter $(\% \mathrm{~m} / \mathrm{v}) ; 22 \mathrm{mg} . \mathrm{L}^{-1}$ of P; $50 \mathrm{mg} . \mathrm{L}^{-1}$ of K; $1.5 \mathrm{cmol}_{\mathrm{c}} \mathrm{dm}^{-3}$ of Al; $1.6 \mathrm{cmol}_{\mathrm{c}} \mathrm{dm}^{-3}$ of $\mathrm{Ca}$ and $1.1 \mathrm{cmol} \mathrm{dm}^{-3}$ of $\mathrm{Mg}$. The contents of exchangeable $\mathrm{Al}^{3+}, \mathrm{Ca}^{2+}$ and $\mathrm{Mg}^{2+}$ were determined by extraction with $\mathrm{KCl}$ solution $1 \mathrm{M}$ followed by atomic absorption spectrophotometry, and $\mathrm{P}^{3-}$ and $\mathrm{K}^{1+}$ were determined by Mehlich- 1 as described by Tedesco (1995). Organic matter was determined by wet combustion method (Díaz-Zorita, 1999).

\subsection{Growth performance analysis}

Lettuce plants were harvested after 37 days (including seedling production) and radish plants after 30 days. The variables used to assess growth performance in the plants were: i) estimated leaf area (lettuce only) was measured at the beginning and end of the experiment with a digital integrator (Sony Cybershot ${ }^{\mathbb{B}}$ 7.2 Mpixels); ii) leaf count (lettuce only); iii) fresh weight (FW) and dry weight (DW) of the leaves (dried in a stove at $60^{\circ} \mathrm{C}$ to a constant weight); iv) FW and DW of roots (the same drying process as the leaves); roots were obtained by sieving the soil present in the $5 \mathrm{~kg}$ bags; v) root diameter (radish only); vi) macronutrient concentrations $(\mathrm{N}, \mathrm{P}, \mathrm{K}, \mathrm{Ca}, \mathrm{Mg})$ in the plant tissues and soil were determined by atomic absorption according to Tedesco (1995); and vii) nitrate $\left(\mathrm{NO}_{3}{ }^{-}\right)$content in lettuce leaves, which was determined by colorimetric analysis through salicylic acid nitration according to Cataldo et al. (1975). The values of leaf dry weight (LDW) and root dry weight (RDW) were used to calculate the ratio $\mathrm{LDW} / \mathrm{RDW}$, which was used to determine the nutrient partition between aerial and underground organs and indirectly estimate physic mechanical properties of stems and roots.

\subsection{Experimental design and statistical analysis}

Vegetative growth experiments were carried out in a completely randomized design. Treatments consisted of four soil bags $(n=4)$ with one lettuce plant and three radish plants each. The plastic bags were placed equidistant in the green house benches ( $15 \mathrm{~cm}$ spacing). In the case of the radish, the three plants were pooled together and represented one biological repetition per bag. The entire experiment consisted of seven treatments. Five treatments contained composted flotation sludge (CFS) (T1 to T5), one treatment composed of plants submitted to chemical fertilizers (QF) (T6), and one control treatment (C) with pure soil. The amount of CFS and QF used in the different treatments is presented in Table 2. The calculation was based on the amount of nitrogen recommended for the cultures since $\mathrm{N}$ is considered a limiting nutrient for both lettuce and radish (Sociedade Brasileira de Ciência do Solo, 2004).

\section{Results and discussion}

The number of leaves in lettuce plants was not significantly different between the treatments that received CFS (T1-T5), although these treatments presented a greater number of leaves than T6 (QF) and control (C) (Table 3). These results are related to the elevated contents of nutrients present in the different composts (Table 1), but more importantly, related to

Table 1. Physicochemical characterization of the composts used for growth performance experiments.

\begin{tabular}{|c|c|c|c|c|c|c|c|c|c|c|}
\hline \multirow{2}{*}{ Treat $^{a}$} & \multirow{2}{*}{$\mathrm{pH}$} & \multirow{2}{*}{$\mathrm{C} / \mathrm{N}^{\mathrm{b}}$} & \multirow{2}{*}{$\begin{array}{c}\mathrm{EC}^{\mathrm{c}} \\
\mathrm{dS} . \mathrm{cm}^{-1}\end{array}$} & \multirow{2}{*}{$\begin{array}{c}\mathrm{MC}^{\mathrm{d}} \\
(\%) \\
\end{array}$} & $\mathrm{C}$ & $\mathrm{N}$ & $\mathrm{P}$ & $\mathrm{K}$ & $\mathrm{Ca}$ & $\mathrm{Mg}$ \\
\hline & & & & & \multicolumn{6}{|c|}{$\left(\mathrm{g} . \mathrm{Kg}^{-1}\right)$} \\
\hline $\mathrm{T} 1$ & 7.48 & $16: 1$ & 3.00 & 60.74 & 524.64 & 33.06 & 4.93 & 19.86 & 18.79 & 6.71 \\
\hline T 2 & 7.43 & $16: 1$ & 2.95 & 59.70 & 507.24 & 31.85 & 12.46 & 20.36 & 17.35 & 7.71 \\
\hline T 3 & 7.57 & $16: 1$ & 2.73 & 54.29 & 520.77 & 31.51 & 4.29 & 16.39 & 15.05 & 5.57 \\
\hline $\mathrm{T} 4$ & 7.35 & $15: 1$ & 2.77 & 54.02 & 495.65 & 33.06 & 4.61 & 20.89 & 18.79 & 6.99 \\
\hline T 5 & 7.48 & $16: 1$ & 2.75 & 55.41 & 526.57 & 32.87 & 0.65 & 13.22 & 12.24 & 4.59 \\
\hline
\end{tabular}

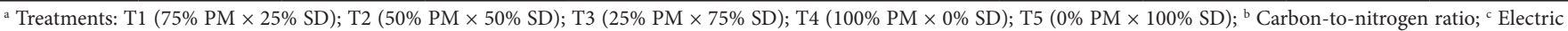
conductivity; ${ }^{\mathrm{d}}$ Moisture content. 
Table 2. Recommended amounts of chemical fertilizers (T6) and composted flotation sludge (T1-T5). Calculations based on nitrogen demands of lettuce and radish crops and nitrogen availability on chemical fertilizers.

\begin{tabular}{|c|c|c|c|c|}
\hline \multirow{2}{*}{ Treat $^{a}$} & \multicolumn{2}{|c|}{$\left(\text { Kg.ha }^{-1}\right)^{c}$} & \multicolumn{2}{|c|}{ Grams in $5 \mathrm{Kg}$ bags } \\
\hline & Lettuce & Radish & Lettuce & Radish \\
\hline $\mathrm{T} 1$ & $18,756.16$ & $3,751.23$ & 46.9 & 9.4 \\
\hline $\mathrm{T} 2$ & $19,461.72$ & $3,892.34$ & 48.7 & 9.7 \\
\hline T 3 & $19,708.85$ & $3,941.77$ & 49.3 & 9.9 \\
\hline T 4 & $18,756.16$ & $3,751.23$ & 46.9 & 9.4 \\
\hline T 5 & $18,870.18$ & $3,774.04$ & 47.2 & 9.4 \\
\hline T6 & \multicolumn{4}{|c|}{$\mathrm{N}-\mathrm{P}_{2} \mathrm{O}_{5}-\mathrm{K}_{2} \mathrm{O}$} \\
\hline $\mathrm{C}^{\mathrm{b}}$ & - & - & - & - \\
\hline
\end{tabular}

Table 3. Number of leaves and leaf area of lettuce plants cultivated in soils fertilized with composted flotation sludge (T1-T5) and chemical fertilizer (T6).

\begin{tabular}{ccccc}
\hline \multirow{2}{*}{ Treat $^{\text {a }}$} & Number of leaves & \multicolumn{2}{c}{ Leaf area $\left(\mathrm{cm}^{2}\right)$} & Fr $>$ F \\
\cline { 3 - 4 } T1 & $20.63 \pm 1.99 \mathrm{a}$ & $123.94 \pm 22.94 \mathrm{D}$ & $1052.1 \pm 51.58 \mathrm{Aa}$ & $<.0001$ \\
T2 & $19.38 \pm 1.43 \mathrm{ab}$ & $132.30 \pm 16.69 \mathrm{D}$ & $1058.7 \pm 175.6 \mathrm{Aa}$ & $<.0001$ \\
T3 & $18.38 \pm 0.72 \mathrm{ab}$ & $119.99 \pm 17.57 \mathrm{D}$ & $863.66 \pm 76.84 \mathrm{Ac}$ & $<.0001$ \\
T4 & $17.88 \pm 0.69 \mathrm{ab}$ & $115.41 \pm 9.34 \mathrm{D}$ & $894.13 \pm 66.01 \mathrm{Abc}$ & $<.0001$ \\
T5 & $17.75 \pm 1.13 \mathrm{ab}$ & $131.25 \pm 23.02 \mathrm{D}$ & $1022.97 \pm 63.23 \mathrm{Aab}$ & $<.0001$ \\
T6 & $16.50 \pm 1.22 \mathrm{~b}$ & $87.41 \pm 7.40 \mathrm{C}$ & $828.53 \pm 79.20 \mathrm{Ac}$ & $<.0001$ \\
C & $8.75 \pm 0.56 \mathrm{c}$ & $90.13 \pm 5.85 \mathrm{~B}$ & $290.41 \pm 27.81 \mathrm{Ae}$ & 0.0498 \\
Pr $>$ F & $<0.0001$ & 0.9978 & $<.0001$ & \\
\hline
\end{tabular}

${ }^{a}$ Treatments: T1 (75\% PM $\times 25 \%$ SD); T2 (50\% PM $\times 50 \%$ SD); T3 (25\% PM $\times 75 \%$ SD); T4 (100\% PM $\times 0 \%$ SD); T5 (0\% PM $\times 100 \%$ SD); T6 (chemical fertilizer); C (control). Number of leaves: Means followed by the distinct lower letters in the columns are considered statistically different by the $t$-Student's test at $5 \%$ significance. Leaf area: Means followed by distinct lower letters in the columns and distinct upper letters in the lines are considered statistically different by the $t$-Student's test at $5 \%$ significance.

the slower rates of nutrient liberation in the soil, maintaining a higher availability throughout the plant development cycle (Chiconato et al., 2013).

Treatments 1 and 2 presented the highest final leaf area and contained larger proportions of poultry manure, thus more available $\mathrm{N}\left(\mathrm{T} 1=33.06 \mathrm{~g} \cdot \mathrm{Kg}^{-1}, \mathrm{~T} 2=31.85 \mathrm{~g} \cdot \mathrm{Kg}^{-1}\right)$.

The organic composts (T1-T5) affected significantly the aerial fresh weight of the lettuce plants (Table 4) compared to QF (T6) and control (C), which was a reflex of the higher number of leaves and leaf area observed in plants fertilized with CFS (Table 3). The increase in FW of lettuce plants supplemented with organic fertilizers were detailed in a previous study (Brasil et al., 2007). Higher proportions of PM led to increases in FW, with exception of T4 (100\% PM). Differently, no significant differences were observed when comparing leaf and root DW, and root FW. Melo Silva et al. (2010) obtained similar LFW production using composted cattle manure at a similar dose $\left(\sim 20\right.$ ton.ha $\left.{ }^{-1}\right)$, in which $\mathrm{N}$ and $\mathrm{K}$ contents were similar to our study; however, $\mathrm{P}$ and $\mathrm{Mg}$ were 10 and 2 times higher, respectively. As observed in this study, LDW was not altered at the same doses of the composts. Lettuce plants are demanding in irrigation and water use of $250 \mathrm{~L} / \mathrm{Kg}(\mathrm{FW}) /$ year is estimated for plants in order to achieve proper development (Barbosa et al., 2015).
Soil amendments with organic fertilizers proved to affect the physical properties of the soil, such as structure, porosity and organic matter content. These factors combined are responsible for an improved water holding capacity (Tejada et al., 2009; Hernández et al., 2016). The soil in the treatments that received CFS (T1-T5) presented a darker color (higher moisture) compared to treatments with QF (T6) and control (C). The occurrence of improved FW in contrast with an unaltered DW may be due to better water use by the plants that are grown in the presence of different proportions of compost. Increases in organic matter, as a response to organic fertilization, are related to better productivity of lettuce plants (Hernández et al., 1992). All treatments that received CFS presented a residual effect in organic matter contents (Table 5) with contents ranging from 1.66 to $2.21 \%$ compared to $1.24 \%$ in $\mathrm{T} 6(\mathrm{QM})$.

In radish plants, no significant difference was observed for LFW between the different treatments containing CFS, and no differences were observed comparing treatments containing CFS and QF. Root fresh weight of radish plants was significantly influenced by the addition of CFS. Treatment $2(36.40 \mathrm{~g})$ had a fresh weight increase of approximately 2 and 10 fold compared to T6 $(12.83 \mathrm{~g})$ and $\mathrm{C}(3.35 \mathrm{~g})$, respectively. In addition, this treatment was the most effective treatment in regards to productivity. The compost used in Treatment 2 (50\% PM-50\% SD) did not 
Table 4. Analysis of leaf fresh weight (LFW), leaf dry weight (LDW), root fresh weight (RFW) and root dry weight (RDW) in lettuce and radish plants fertilized with composted flotation sludge (T1-T5) and chemical fertilizer (T6). Results are expressed in grams (g).

\begin{tabular}{|c|c|c|c|c|c|}
\hline \multicolumn{6}{|c|}{ Lettuce } \\
\hline Treat $^{\mathrm{a}}$ & LFW & LDW & RFW & RDW & Ratio LDW/RDW \\
\hline T1 & $138.08 \pm 12.58 \mathrm{a}$ & $17.61 \pm 1.36$ & $8.24 \pm 1.86$ & $3.86 \pm 0.46$ & $4.92 \pm 0.75$ \\
\hline $\mathrm{T} 2$ & $134,93 \pm 18.87 \mathrm{ab}$ & $16.66 \pm 0.98$ & $7.7040 \pm 2.64$ & $3.60 \pm 0.61$ & $5.21 \pm 0.37$ \\
\hline T3 & $110.14 \pm 8.45 \mathrm{abc}$ & $16.16 \pm 0.72$ & $8.2643 \pm 2.45$ & $3.35 \pm 0.36$ & $5.00 \pm 0.56$ \\
\hline $\mathrm{T} 4$ & $112.45 \pm 8.67 \mathrm{abc}$ & $15.00 \pm 1.61$ & $8.0643 \pm 0.64$ & $3.31 \pm 0.07$ & $4.57 \pm 0.47$ \\
\hline T5 & $107.01 \pm 9.28 \mathrm{bc}$ & $16.90 \pm 1.13$ & $12.31 \pm 2.03$ & $3.96 \pm 0.40$ & $4.45 \pm 0.30$ \\
\hline T6 & $93.28 \pm 9.54 \mathrm{c}$ & $15.68 \pm 1.65$ & $4.5040 \pm 0.23$ & $2.85 \pm 0.07$ & $5.47 \pm 0.48$ \\
\hline $\mathrm{C}$ & $23.95 \pm 2.03 \mathrm{~d}$ & $13.00 \pm 1.20$ & $5.7745 \pm 0.94$ & $2.77 \pm 0.06$ & $4.68 \pm 0.41$ \\
\hline $\operatorname{Pr}>\mathrm{F}$ & $<0.0001$ & 0.1579 & 0.1211 & 0.1181 & 0.7777 \\
\hline \multicolumn{6}{|c|}{ Radish } \\
\hline $\mathrm{T} 1$ & $32.49 \pm 1.65 \mathrm{a}$ & $4.06 \pm 0.12 \mathrm{~b}$ & $31.32 \pm 3.79 \mathrm{ab}$ & $3.59 \pm 0.21 b$ & $1.15 \pm 0.05 \mathrm{bc}$ \\
\hline $\mathrm{T} 2$ & $33.49 \pm 0.71 \mathrm{a}$ & $4.34 \pm 0.09 \mathrm{ab}$ & $36.40 \pm 1.17 \mathrm{a}$ & $4.25 \pm 0.12 \mathrm{a}$ & $1.03 \pm 0.01 \mathrm{c}$ \\
\hline T3 & $30.94 \pm 1.56 \mathrm{a}$ & $4.13 \pm 0.18 \mathrm{ab}$ & $25.77 \pm 2.50 \mathrm{~b}$ & $3.61 \pm 0.19 \mathrm{~b}$ & $1.17 \pm 0.06 \mathrm{abc}$ \\
\hline $\mathrm{T} 4$ & $32.90 \pm 0.92 \mathrm{a}$ & $4.56 \pm 0.15 \mathrm{a}$ & $27.44 \pm 1.80 \mathrm{~b}$ & $3.99 \pm 0.20 \mathrm{ab}$ & $1.16 \pm 0.02 \mathrm{bc}$ \\
\hline T5 & $29.12 \pm 1.65 \mathrm{a}$ & $4.45 \pm 0.07 \mathrm{ab}$ & $27.43 \pm 2.96 \mathrm{~b}$ & $3.98 \pm 0.15 \mathrm{ab}$ & $1.13 \pm 0.03 b c$ \\
\hline T6 & $28.94 \pm 6.56 \mathrm{a}$ & $3.49 \pm 0.31 \mathrm{c}$ & $12.83 \pm 0.93 c$ & $2.62 \pm 0.03 c$ & $1.33 \pm 0.12 \mathrm{a}$ \\
\hline C & $5.73 \pm 0.26 c$ & $2.60 \pm 0.08 \mathrm{~d}$ & $3.35 \pm 0.05 \mathrm{~d}$ & $2.64 \pm 0.10 c$ & $1.03 \pm 0.01 \mathrm{bc}$ \\
\hline $\operatorname{Pr}>F$ & $<0.0001$ & $<0.0001$ & $<0.0001$ & $<0.0001$ & 0.0260 \\
\hline
\end{tabular}

Means followed by distinct letters in the columns are considered statistically different by the $t$-Student's test at $5 \%$ significance. ${ }^{\text {a }}$ Treatments: 11 ( $75 \%$ PM $\times 25 \%$ SD); 2 ( $50 \%$ PM $\times 50 \%$ SD); T3 (25\% PM $\times 75 \% \mathrm{SD})$; T4 (100\% PM $\times 0 \% \mathrm{SD})$; T5 (0\% PM $\times 100 \% \mathrm{SD})$; T6 (chemical fertilizer); C (control).

Table 5. Physicochemical characterization and residual concentrations of macronutrients in the soil after cultivation with lettuce and radish.

\begin{tabular}{|c|c|c|c|c|c|c|c|c|}
\hline \multicolumn{9}{|c|}{ Lettuce } \\
\hline Treat $^{\mathrm{a}}$ & $\begin{array}{l}\text { Clay } \\
(\%)\end{array}$ & $\begin{array}{c}\mathrm{pH} \\
\left(\mathrm{H}_{2} \mathrm{O}\right)\end{array}$ & $\begin{array}{c}\mathrm{OM} \\
(\% \mathrm{~m} / \mathrm{v})\end{array}$ & \multicolumn{3}{|c|}{ N P K mg. Kg ${ }^{-1}$} & \multicolumn{2}{|c|}{$\mathrm{Ca} \mathrm{Mg} \mathrm{cmol}{ }_{c} \cdot \mathrm{dm}^{-3}$} \\
\hline T1 & 26 & 5.3 & 1.79 & 12.4 & 50.9 & 118.0 & 3.5 & 2.0 \\
\hline $\mathrm{T} 2$ & 26 & 5.3 & 1.79 & 14.7 & 50.9 & 127.0 & 3.7 & 2.0 \\
\hline T3 & 26 & 5.3 & 2.21 & 11.7 & 50.9 & 116.0 & 3.8 & 2.0 \\
\hline $\mathrm{T} 4$ & 29 & 5.1 & 1.79 & 13.6 & 45.1 & 114.0 & 3.4 & 1.8 \\
\hline T5 & 16 & 5.2 & 1.66 & 10.9 & 50.9 & 88.0 & 3.9 & 1.9 \\
\hline T6 & 19 & 4.9 & 1.24 & 17.2 & 52.1 & 336.0 & 3.0 & 1.3 \\
\hline $\mathrm{C}$ & 19 & 4.9 & 1.24 & 6.4 & 8.1 & 68.0 & 2.6 & 1.3 \\
\hline \multicolumn{9}{|c|}{ Radish } \\
\hline T1 & 27 & 5.2 & 1.58 & 13.3 & 11.6 & 104.0 & 2.9 & 1.4 \\
\hline $\mathrm{T} 2$ & 26 & 5.2 & 1.66 & 14.4 & 8.1 & 82.0 & 2.9 & 1.3 \\
\hline T3 & 25 & 5.4 & 1.90 & 11.7 & 33.6 & 97.0 & 3.6 & 1.8 \\
\hline $\mathrm{T} 4$ & 26 & 5.2 & 1.58 & 10.5 & 9.3 & 87.0 & 2.6 & 1.3 \\
\hline T5 & 28 & 5.2 & 1.66 & 14.6 & 6.9 & 70.0 & 2.8 & 1.3 \\
\hline T6 & 27 & 5.0 & 1.79 & 15.1 & 40.5 & 435.0 & 2.8 & 1.0 \\
\hline $\mathrm{C}$ & 26 & 5.0 & 1.24 & 6.1 & 6.9 & 70.0 & 2.8 & 1.3 \\
\hline
\end{tabular}

a Treatments: T1 (75\% PM $\times 25 \%$ SD); T2 (50\% PM × 50\% SD); T3 (25\% PM × 75\% SD); T4 (100\% PM × 0\% SD); T5 (0\% PM $\times 100 \%$ SD); T6 (chemical fertilizer); C (control);

present the highest nutrient content, although it produced the best effects on root fresh weight and root diameter (Table 6). This finding may be related to the physical characteristics of the soil, as greater proportions of SD in T2 may have improved soil porosity and aeration. Another fact to be considered is the characteristics of the soil used in this experiment, being classified as sandy clay loam (Sociedade Brasileira de Ciência do Solo, 2004) with reduced incidence of macro pores. Regarding radish RDW, the differences were proportional to those observed in RFW; however, no difference was observed between the weight of C (2.64 g) and T6 (2.62 g).
No significant differences occurred in root diameter when comparing treatments that received CFS (T1-T5). On the other hand, QF (T6) resulted in smaller roots $(1.15 \mathrm{~cm})$, which is approximately half the diameter of roots in amended soils (Figure 1).

The concentration of macronutrients in lettuce leaves follows a pattern that is mostly influenced by the proportions of PM as bulking agent (Table 6). From T1 to T3, the proportions of PM decreased from $75 \%$ to $25 \%$ and a gradual decrease in concentration was observed for $\mathrm{P}$ and $\mathrm{K}$. For $\mathrm{Ca}, \mathrm{Mg}$ and $\mathrm{N}$ this tendency was 
Oliveira et al.

Table 6. Concentration of macronutrients (g. $\mathrm{Kg}^{-1}$ dry weight) in the leaves and roots of lettuce and radish plants fertilized with composted flotation sludge (T1-T5) and chemical fertilizer (T6).

\begin{tabular}{|c|c|c|c|c|c|c|c|c|c|c|}
\hline \multirow{3}{*}{ Treat $^{a}$} & \multicolumn{10}{|c|}{ Lettuce } \\
\hline & \multicolumn{5}{|c|}{ Leaves } & \multicolumn{5}{|c|}{ Roots } \\
\hline & $\mathrm{P}$ & $\mathrm{K}$ & $\mathrm{Ca}$ & $\mathrm{Mg}$ & $\mathrm{N}$ & $\mathrm{P}$ & $\mathrm{K}$ & $\mathrm{Ca}$ & $\mathrm{Mg}$ & $\mathrm{N}$ \\
\hline $\mathrm{T} 1$ & 6.06 & 68.29 & 10.79 & 4.61 & 29 & 7.02 & 7.88 & 16.58 & 9.65 & 0.25 \\
\hline $\mathrm{T} 2$ & 5.93 & 67.24 & 8.86 & 4.00 & 25 & 6.94 & 6.30 & 15.44 & 11.86 & 0.21 \\
\hline $\mathrm{T} 3$ & 5.05 & 58.83 & 9.47 & 4.34 & 30 & 5.46 & 9.72 & 10.35 & 8.31 & 0.22 \\
\hline $\mathrm{T} 4$ & 6.34 & 71.44 & 11.32 & 4.99 & 41 & 5.69 & 10.24 & 11.67 & 7.03 & 0.35 \\
\hline T5 & 4.95 & 46.75 & 8.16 & 3.81 & 15 & 4.95 & 7.09 & 9.65 & 16.46 & 0.2 \\
\hline T6 & 7.67 & 63.04 & 7.98 & 4.52 & 29 & 4.93 & 6.57 & 12.72 & 8.68 & 0.2 \\
\hline $\mathrm{C}$ & 1.27 & 26.53 & 5.61 & 2.84 & 24 & 5.13 & 11.82 & 8.86 & 4.85 & 0.19 \\
\hline \multicolumn{11}{|c|}{ Radish } \\
\hline $\mathrm{T} 1$ & 5.01 & 38.09 & 19.21 & 6.99 & 35 & 2.72 & 36.25 & 3.54 & 2.1 & 0.31 \\
\hline $\mathrm{T} 2$ & 1.15 & 35.72 & 18.51 & 7.19 & 33 & 3.85 & 38.87 & 3.56 & 3.04 & 0.3 \\
\hline T3 & 1.55 & 37.3 & 18.86 & 7.97 & 35 & 4.24 & 32.83 & 3.63 & 2.23 & 0.42 \\
\hline $\mathrm{T} 4$ & 2.86 & 35.98 & 16.93 & 7.51 & 42 & 4.58 & 32.71 & 3.58 & 1.94 & 0.35 \\
\hline T5 & 1.9 & 33.36 & 19.47 & 7.82 & 29 & 4.34 & 36.25 & 4.39 & 2.21 & 0.22 \\
\hline T6 & 7.1 & 67.24 & 14.39 & 6.26 & 30 & 5.36 & 49.9 & 3.13 & 1.83 & 0.25 \\
\hline $\mathrm{C}$ & 3.56 & 30.73 & 17.02 & 6.66 & 29 & 3.42 & 32.94 & 5.61 & 2.93 & 0.25 \\
\hline
\end{tabular}

a Treatments: T1 $(75 \% \mathrm{PM} \times 25 \% \mathrm{SD}) ; \mathrm{T} 2(50 \% \mathrm{PM} \times 50 \% \mathrm{SD}) ; \mathrm{T} 3(25 \% \mathrm{PM} \times 75 \% \mathrm{SD}) ; \mathrm{T} 4(100 \% \mathrm{PM} \times 0 \% \mathrm{SD}) ; \mathrm{T} 5$ (0\% PM $\times 100 \% \mathrm{SD}) ; \mathrm{T} 6(\mathrm{chemical}$ fertilizer); C (control).

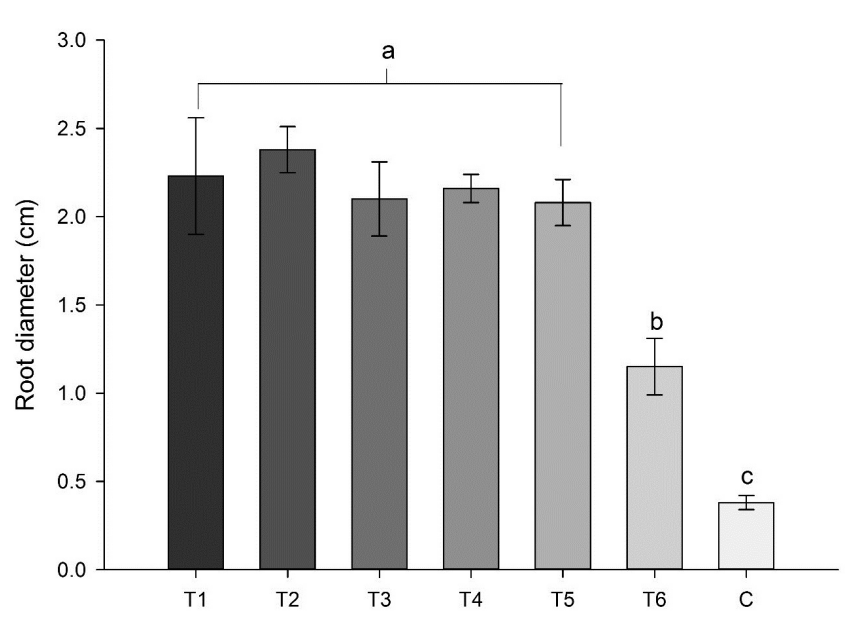

Figure 1. Root diameter of radish plants cultivated in different treatments; $\mathrm{T} 1(75 \% \mathrm{PM} \times 25 \% \mathrm{SD}) ; \mathrm{T} 2(50 \% \mathrm{PM} \times 50 \% \mathrm{SD}) ; \mathrm{T} 3(25 \% \mathrm{PM} \times 75 \% \mathrm{SD})$; T4 (100\% PM $\times 0 \%$ SD); T5 (0\% PM $\times 100 \%$ SD); T6 (chemical fertilizer); C (control). Different letters indicate statistical difference by Tuckey's test at $5 \%$ significance.

not observed, with T3 presenting higher concentrations than T2. Treatment 4 (100\% PM) presented the highest concentrations of macronutrients with exception of $\mathrm{P}$, which was more concentrated in T6 (QM). Among the treatments that received CFS, the lowest concentrations were observed in T5, as a reflex of the lower initial contents of macronutrients in this compost (Table 1). This treatment presented $\mathrm{N}$ concentrations $\left(0.15 \mathrm{~g} \cdot \mathrm{Kg}^{-1}\right)$ even lower than the control treatment $(\mathrm{C})$. As expected, the lowest concentrations were observed in the control treatment, with the exception of N. In the roots, no clear pattern could be observed.
The contents of N, P and Ca seemed to accumulate more in tissues of plants grown in treatments with reduced proportions of PM, which is an inverse tendency compared to the accumulation in leaves. The contents of nitrates $\left(\mathrm{NO}_{3}^{-}\right)$in lettuce leaves were as follows: T1 (0.255 g. $\left.\mathrm{Kg}^{-1}\right)$; T2 (0.210 g. Kg-1 $)$; T3 (0.220 g. $\left.\mathrm{Kg}^{-1}\right)$; T4 (0.325 g. Kg $\left.{ }^{-1}\right)$; T5 (0.200 g. $\left.\mathrm{Kg}^{-1}\right)$; T6 (0.205 g. $\left.\mathrm{Kg}^{-1}\right)$; and C $\left(0.190 \mathrm{~g} \cdot \mathrm{Kg}^{-1}\right)$. The European Union constantly updates the legislation regarding the maximum concentrations of nitrate ion in foodstuff and established that, for lettuce cultivated in greenhouses, fresh tissues should not exceed $5 \mathrm{~g} \cdot \mathrm{Kg}^{-1}$ of $\mathrm{NO}_{3}^{-}$. All treatments remained below this maximum; however, those containing CFS had greater contents than T6, with the exception of T5 (100\% SD). The contents of poultry manure in the composts directly influenced nitrate content in plant tissues. According to Viana \& Vasconcelos (2008), a rapid increment in nitrate concentration in soil is observed 15 days after fertilization with pure poultry manure, from $0.5 \mathrm{mg} \cdot \mathrm{Kg}^{-1}$ to $3.5 \mathrm{mg} \cdot \mathrm{Kg}^{-1}$, consequently decreasing to initial concentrations after 30 days of cultivation with lettuce.

A small variation was observed in the concentration of macronutrients in radish leaves from $\mathrm{T} 1$ to $\mathrm{T} 5$, with exception of $\mathrm{P}$ with a concentration of $5.01 \mathrm{~g} . \mathrm{Kg}^{-1}$ in T1 (Table 6). Phosphorus and $\mathrm{K}$ were more present in T6 (QM); however, $\mathrm{N}$ was more concentrated in the leaves of plants grown in T4 (100\% PM). In the roots, the concentrations of $\mathrm{P}$ and $\mathrm{K}$ were greater in $\mathrm{T} 6$, which was the same observed in the leaves. The highest contents of nitrogen were observed in T3 and T4, with 0.42 and $0.35 \mathrm{~g} . \mathrm{Kg}^{-1}$, respectively. Interestingly, $\mathrm{Ca}$ and $\mathrm{Mg}$ were more concentrated in the roots of plants grown in pure soil (C).

The soil used for plant cultivation was analyzed after harvesting the cultures (Table 5). The $\mathrm{pH}$ of the soil was increased in all treatments that received CFS, for both lettuce and radish 
(4.8 to 5.3); however, a smaller increase was observed in $\mathrm{T} 6$ and $\mathrm{C}$ (4.9 and 5.0). The organic waste originated from slaughterhouse facilities has a potential to decrease the potential acidity of the soil, not to mention improvements in action exchange capacities, base saturation and $\mathrm{Ca}, \mathrm{Mg}, \mathrm{Zn}$ and $\mathrm{P}$ content (Strojaki et al., 2014).

The content of organic matter in lettuce bags was also affected by compost addition, with increases in all treatments (T1-T5) and a decrease in T6 and C. In the radish cultivation, T6 also increased organic matter content. Higher proportions of SD in the different treatments directly influenced residual organic matter content. The residual $\mathrm{N}$ was higher in the soils that received QM (17.2 mg. $\mathrm{Kg}^{-1}$ for lettuce and $15.1 \mathrm{mg} \cdot \mathrm{Kg}^{-1}$ for radish); however, the differences in residual $\mathrm{N}$ between $\mathrm{QF}$ and CFS were not high. For lettuce, similar residual contents of $\mathrm{P}$ were observed in the soil after cultivation and T6 (QM) had the highest residual P content (52.1 mg.L. $\mathrm{L}^{-1}$ ). The residual P content presented a greater variation in radish cultivation among the treatments that received CFS, and $\mathrm{T} 3$ presented a residual $\mathrm{P}$ of $33.6 \mathrm{mg} . \mathrm{L}^{-1}$, just slightly lower than T6 (40.5 mg.L $\left.\mathrm{L}^{-1}\right)$. Similar contents of macronutrients in soil amended with composted PM, following radish harvest, were observed by (Hiranmai, 2015), however, NPK fertilization resulted in much smaller residual content of $\mathrm{P}\left(9 \mathrm{mg} \cdot \mathrm{Kg}^{-1}\right)$ and $\mathrm{K}\left(89 \mathrm{mg} \cdot \mathrm{Kg}^{-1}\right)$ than those observed in this study. The content of $\mathrm{P}$ in root tissues of radish in T5 (Table 6) were also the highest between the different treatments, which indicates that $\mathrm{P}$ availability in T6 was high, therefore accumulating in tissues and remaining as a residue in the soil. However, the best results of RFW, RDW and root diameter were obtained in treatments that received CFS. Similarly to P, the residual content of $\mathrm{K}$ in the soil was extremely high in $\mathrm{T} 6$ for both lettuce and radish. On the other hand, Calcium and $\mathrm{Mg}$ ions were more concentrated in the treatments that received CFS.

\section{Conclusion}

The concentrations of macronutrients in lettuce leaves were influenced directly by the contents of poultry manure in the bulking agent mixture. Higher proportions of poultry manure resulted in a greater intake of $\mathrm{P}$ and $\mathrm{K}$. The concentrations of nitrate in plant tissues followed the same tendency and were directly influenced by poultry manure content. However, the accumulation of $\mathrm{Ca}, \mathrm{Mg}$ and $\mathrm{N}$ did not present this tendency. Nitrogen demands of plants were satisfactorily met by the application of composted flotation sludge, which is confirmed by the increases in productivity of 1.4 fold of leaf fresh weight (Treatment 1) compared to plants cultivated in the presence of chemical fertilizers. The use of poultry manure was fundamental as a source of readily available nitrogen for plant development. However, the exclusive use of poultry manure as bulking agent did not present the best results of leaf fresh weight in lettuce plants. For radish plants, the highest increments were obtained in T2 (50\% poultry manure and $50 \%$ sawdust) with root fresh weight and root diameter incremented in two fold compared to chemical fertilization. In this manner, soil fertility alone may not be a determinant factor in radish root development, and greater content of sawdust in compost (50\%) played an important role in root development. This was likely due to better physical characteristics of the soil, such as higher porosity and aeration which favors root development.

\section{References}

Ahlburg, D. A., Kelley, A. C., \& Mason, K. O. (2013). The impact of population growth on well-being in developing countries. New York: Springer.

Barbosa, G., Gadelha, F. D., Kublik, N., Proctor, A., Reichelm, L., Weissinger, E., Wohlleb, G. M., \& Halden, R. U. (2015). Comparison of land, water, and energy requirements of lettuce grown using hydroponic vs. conventional agricultural methods. International Journal of Environmental Research and Public Health, 12(6), 68796891. PMid:26086708. http://dx.doi.org/10.3390/ijerph120606879.

Brasil, M. V., Vitti, M. R., \& Morselli, T. B. A. (2007). Efeito da adubação orgânica em alface cultivada em ambiente protegido. Cadernos de Agroecologia, 2(1), 1313-1316.

Cataldo, D., Maroon, M., Schrader, L., \& Youngs, V. (1975). Rapid colorimetric determination of nitrate in plant tissue by nitration of salicylic acid 1. Communications in Soil Science and Plant Analysis, 6(1), 71-80. http://dx.doi.org/10.1080/00103627509366547.

Chiconato, D. A., Simoni, F., Galbiatti, J. A., Franco, C. F., \& Caramelo, A. D. (2013). Resposta da alface à aplicação de biofertilizante sob dois níveis de irrigação. Bioscience Journal, 29(2) 392-399.

Díaz-Zorita, M. (1999). Soil organic carbon recovery by the Walkley-Black method in a typic hapludoll. Communications in Soil Science and Plant Analysis, 30(5-6), 739-745. http://dx.doi. org/10.1080/00103629909370242.

Hernández, T., Chocano, C., Moreno, J.-L., \& García, C. (2016). Use of compost as an alternative to conventional inorganic fertilizers in intensive lettuce (Lactuca sativa L.) crops: effects on soil and plant. Soil \& Tillage Research, 160, 14-22. http://dx.doi.org/10.1016/j. still.2016.02.005.

Hernández, T., García, C., Costa, F., Valero, J. A., \& Ayuso, M. (1992). Utilización de residuos urbanos como fertilizantes orgánicos. Suelo y Planta, 2(3), 373-383.

Hiranmai, Y. R. (2015). Influence of organic manuring on the post harvest soil quality of chickpea and radish grown after chickpea. Science Technology and Arts Research Journal, 4(1), 45-49. http:// dx.doi.org/10.4314/star.v4i1.6.

Klerkx, L., Van Mierlo, B., \& Leeuwis, C. (2012). Evolution of systems approaches to agricultural innovation: concepts, analysis and interventions. In I. Darnhofer, D. Gibbon \& B. Dedieu (Eds.), Farming systems research into the 21st century: the new dynamic (pp. 457-483). Dordrecht: Springer.

Linhares, P. C. F., Pereira, M. F. S., Oliveira, B. S., Henriques, G. P. D. S. A., \& Maracaja, P. B. (2010). Produtividade de rabanete em sistema orgânico de produção. Revista Verde de Agroecologia e Desenvolvimento Sustentável, 5(5), 94-101.

Melo Silva, F. A., Villas Bôas, R. L., \& Silva, R. B. (2010). Resposta da alface à adubação nitrogenada com diferentes compostos orgânicos em dois ciclos sucessivos. Acta Scientiarum. Agronomy, 32(1), 131-137.

Montemurro, F., Ciaccia, C., Leogrande, R., Ceglie, F., \& Diacono, M. (2015). Suitability of different organic amendments from agro-industrial wastes in organic lettuce crops. Nutrient Cycling in Agroecosystems, 102(2), 243-252. http://dx.doi.org/10.1007/s10705-015-9694-5.

Sociedade Brasileira de Ciência do Solo. Comissão de Química e Fertilidade do Solo - Núcleo Regional Sul. (2004). Manual de adubação e calagem para os Estados do Rio Grande do Sul e de Santa Catarina (10. ed.). Porto Alegre: SBCS. 
Strojaki, T. V., Silva, V. R. D., Ros, C. O. D., Silva, R. F. D., \& Somavilla, A. (2014). Alterações químicas em latossolo vermelho submetido a doses crescentes de resíduo orgânico de agroindústria frigorífica. Enciclopédia Biosfera, 10(18), 190.

Tedesco, M. J. (1995). Analises de solo, plantas e outros materiais. Porto Alegre: UFRGS.
Tejada, M., Hernandez, M. T., \& Garcia, C. (2009). Soil restoration using composted plant residues: effects on soil properties. Soil \& Tillage Research, 102(1), 109-117. http://dx.doi.org/10.1016/j. still.2008.08.004.

Viana, E. M., \& Vasconcelos, A. C. F. (2008). Produção de alface adubada com termofosfato e adubos orgânicos. Revista Ciência Agronômica, 39(2), 217-224. 